\title{
Factors Affecting Job Motivation among Faculty Members: Evidence from Vietnamese Public Universities
}

\author{
The Tuan TRAN', Quang Hung DO²
}

Received: July 03, 2020 Revised: July 28, 2020 Accepted: August 10, 2020

\begin{abstract}
Higher education has long been considered as a means of human resource development in a nation. The faculty member plays a significant role in improving the quality of higher education. It is clear that job satisfaction and motivation have effect on the faculty member's performance. The objective of this study is to investigate the levels and factors affecting lecturers' motivation in Vietnamese public universities. In this study, ordinary least squares (OLS) and exploratory factor analysis (EFA) have been utilized to identify the factors affecting work motivation of lecturers at Vietnamese universities. A questionnaire was administered to a sample of 189 lecturers at different public universities in Vietnam. The finding indicates that seven factors including Work characteristics (WC), Wage and welfare (WW), Social recognition (SR), Peer relationships (PR), Training and promotion opportunities (PO), Leader caring (LC) and Teacherstudent interaction and student's attitude (IA) have positive effect on lecturers' work motivation. Among these factors, Teacher-student interaction and student's attitude (IA) has the strongest impact with the coefficient of 0.631 and Peer relationships (PR) has the least impact on work motivation with the coefficient of 0.020 . The study findings can facilitate the understanding of how to increase work satisfaction at the universities in Vietnam.
\end{abstract}

Keywords: Job Motivation, Job Satisfaction, Lecturers, Universities, Vietnam

JEL Classification Code: O15, D91, I23

\section{Introduction}

Work motivation plays a prominent role within and outside of the workers to feel compelled, aroused and excited in running their activity. Moreover, work motivation can increase the productivity when other inputs remain unchanged (Jusmin, Said, Bima, \& Alam, 2016). Lecturer is the most strategic element of education to create quality in education, its active participation and role give large contribution in achieving the goal of education nationally. The importance

${ }^{1}$ First Author. Lecturer, Faculty of Transport Economics, University of Transport Technology, Email: tuantt83@utt.edu.vn

${ }^{2}$ Corresponding Author. Senior Lecturer, Faculty of Information Technology, University of Transport Technology, Vietnam [Postal Address: No 54, Trieu Khuc, Thanh Xuan Nam, Hanoi 100000, Vietnam] Email: hungdq@utt.edu.vn

() Copyright: The Author(s)

This is an Open Access article distributed under the terms of the Creative Commons Attribution Non-Commercial License (https://creativecommons.org/licenses/by-nc/4.0/) which permits unrestricted non-commercial use, distribution, and reproduction in any medium, provided the original work is properly cited. of lecturer's role makes the necessity of motivation and job satisfaction in creating qualified performance.

Work motivation include two factors: intrinsic factors and extrinsic factors. Intrinsic factors are what bring job satisfaction, on the other hand, extrinsic factors bring dissatisfaction and reduce the level of job satisfaction. The intrinsic factors are also called satisfiers and motivators, included creative or challenging work, responsibility and advancement opportunities. It is believed that intrinsic motivation, which is the motivation to perform an activity, can help employees experience the pleasure and satisfaction inherent in the activity. Particularly, it is believed that intrinsic job satisfaction was how employees feel about the jobs themselves, or the nature of the job. While extrinsic job satisfaction was how employees feel about the aspects outside of the work itself. Rewards that are interpreted as information about one's competence and satisfy individuals' need for autonomy, will enhance intrinsic motivation (Phuong, Khuong, Phuc, \& Dong, 2018). Motivation factors lead to positive mental health and challenge people to grow, contribute to the work environment and invest 
themselves in the organization. Academic performance is the outcome of education; the extent to which a student, lecturer or institution has achieved their educational goals (Victor \& Babatunde, 2014). Lecturers play the mentoring role for their students in higher institutions of learning; their primary motivation is associated with students learning achievement. Furthermore, reviewing the previous studies on lecturer's motivation, different authors have explored various issues of motivation for lecturers in higher educational institutions which can be valuable contribution in enhancing job satisfaction and involvement in particular and for organizational growth as whole. The crucial task of educational manager and human resource management in universities or higher education institutions is always centered to enhance the job satisfaction level, particularly of lecturers as they are building blocks of institution as well as society at large.

The objective of this study is to identify the factors affecting work motivation of lecturers at public universities located in Hanoi, Vietnam by the use of the exploratory factor analysis (EFA) and ordinary least squares regression (OLS). Then, several suggestions are also offered to improve the work motivation of lecturers in Vietnam. After introduction, the paper is organized as follows. Section 2 is devoted to literature review; Section 3 presents research methodology; results and discussions are exhibited in Section 4; and finally, Section 5 concludes the study.

\section{Literature Review}

Several factors have been identified in the literature that are claimed to have an effect on job motivation of lecturers. Based on findings of previous studies, a number of factors are discussed as follows.

\subsection{Work Motivation (WM)}

Giving motivation to the organization aims to encourage the working spirit of employees to be willing to work hard by giving all their abilities. If the employee is motivated, then he/she will get satisfaction in the work, and he/she works more enthusiastically, which will eventually improve his/her performance (Pancasila, Haryono, \& Sulistyo, 2020). Motivation can be defined as the processes that account for an individual's intensity, direction, and persistence of effort (Baron, 1991). Motivation can be also explained as the process that initiates, guides, and maintains goal-oriented behaviors in all activities. Lecturers are assigned to convey knowledge and skills to students. In general, if lecturers are satisfied, teaching is more effective and can affect students' achievement (Mertler, 1992). An enthusiastic lecturer usually has dedicated commitment to devote him/herself to work. It means that they will prepare, teach and evaluate students' work on time and assume their responsibilities as always top priority (Aaronson, Barrow, \& Sander, 2007; Ai, My, \& Chieu, 2019).

\subsection{Work Characteristics (WC)}

Work characteristics have a profound impact on employee well-being, work engagement and job satisfaction (Bos, Donders, Bouwman-Brouwer, \& van der Gulden, 2009). In the field of education, lecturers work in a flat, craft-style organizational structure, their work is primarily with students, they are physically isolated from the continuous interactions with other adults that characterize most business work and are faced with qualitatively based, subjective judgements of effectiveness. They may be motivated quite differently than are business workers (Barnabé \& Burns, 1994). Job characteristics include job autonomy, job feedback, diversity, task identity, and task importance. Job autonomy refers to the independent discretion of the employee in performing the task. High autonomy can be found in the increase of creativity and selfdevelopment tendencies due to the high level of control and ownership of ideas in the performance of tasks. Job feedback is related to the degree of providing accurate information to recognize the progress, status, and results of a task. In other words, job feedback gives information about the certainty and suitability of his/her work behavior like informational function. The remaining characteristics (diversity, task identity, and task importance) emphasize the design aspect of the job with regard to the meaningful experience of the job (Lee, 2018).

\subsection{Wage and Welfare (WW)}

The findings of previous studies reveal that Vietnamese lecturers face many difficulties in terms of salary and welfare to work well in their profession. Salary and social welfare policies for lecturers in public universities are greatly influenced by the legal documents prescribed by the Government, so many lecturers are not satisfied and have not devoted themselves (Munyengabe, He, \& Yiyi, 2016).

\subsection{Social Recognition (SR)}

In an academic environment, social recognition can be considered as the judgment, which is provided to an academic for being a valued individual of his/her university and society. If recognition or rewards provided to lecturers are to be changed, then there will be a consequent change in the job satisfaction and work motivation (Amarasena, Ajward, \& Ahasanul Haque, 2015). 


\subsection{Peer Relationships (PR)}

Peer relationships at work are one of the primary means by which organizational socialization takes place (Morrison \& Nolan, 2009). Lecturer motivation and well-being are not only affected by stressors or job demands but have also been shown to be related to positive aspects of the work, which are often termed job resources. For example, good peer relations with colleagues and the school administration as well as the feeling of doing a meaningful job have been shown to be positively related to lecturers' engagement and well-being and negatively related to teacher stress (Skaalvik \& Skaalvik, 2018).

\subsection{Training and Promotion Opportunities (PO)}

Training and promotion opportunity influences employees' career expectations about their long-term future within the organization. Promotion opportunities indicate to employees that career advancement is possible. Moreover, promotion opportunities offer incentives and challenges for employees to take on, thereby providing additional extrinsic and intrinsic motivation. Conversely, limited promotion opportunities are likely to reduce internal career expectations and encourage external job search (Frenkel \& Bednall, 2016).

\subsection{Leader Caring (LC)}

Employees feel motivated because adaptive leaders inspire and influence them rather than just demonstrating hierarchical command and control. If leaders are interested in the feelings and needs of the employees, and guide them to achieve their goals; Therefore, the employees will be improved their interest in work. Leaders should use their vision to encourage employees to make efforts beyond expectations. Specifically, the leader uses the symbols, metaphors and simple appeals to raise awareness and understanding about common goals of employees. The inspirational ability is that leaders use mental images to evoke vividly the charismatic picture of the future, thereby increasing the motivation of employees to help them achieve outstanding achievements. The inspirational leader also promotes the excitement and meaning of work for employees. It is showed that the inspirational leader will increase the concentration and energy of employees when working (Nguyen, Mai, \& Huynh, 2019). Dynamic leaders are appreciative of teams and the contribution of each employee; they are supportive of employees in different situations, are caring, fair, humble and inspiring. All these characteristics help a dynamic leader motivate teams rather than just individuals (Rahbi, Khalid, \& Khan, 2017).

\subsection{Teacher-Student Interaction and Student's Attitude (IA)}

It was found that teacher-student interaction and student's attitude are factors affecting motivation and job satisfaction of lecturers within a university (Munyengabe, Haiyan, Yiyi, \& Jiefei, 2017). It is a common sense that an individual attitude can be positive or negative. Positive student's attitudes towards lecturers is paramount in academic environment which make lecturers have more motivation in their work.

\section{Research Methodology}

\subsection{Scales of Measurement}

The data were collected in several successive steps. First, focus groups were conducted to explore the factors affecting job motivation of lecturers. Next, focus groups pre-tested the questionnaire, and identified additional variables (that could affect the dependent variable) not present in the original survey instrument. A pilot survey was conducted, and reached 19 lecturers and managers in different universities. Then, the instrument was modified, once again, for the final survey (see Table 1). The questions were asked on a 5-point Likert scale: (1) Strongly disagree; (2) Disagree; (3) Neither agree nor disagree; (4) Agree; (5) Strongly agree.

\subsection{Sample and Data Collection}

The method of sample size $(\mathrm{N})$ calculation for multiple regression has been suggested by Green (Green, 1991) as: $\mathrm{N} \geq 50+8 \mathrm{p}$, where $\mathrm{p}$ is the number of independent variables. In this study, the number of independent variables is 7; therefore, the minimum value of sample size is 106. A total of 200 questionnaires were delivered between March 2020 and June 2020, and 189 valid responses were returned, representing a response rate of $94.5 \%$.

\subsection{Data Analysis}

The data analysis was conducted as follows. First, Cronbach's alpha coefficients were calculated. To be accepted, Cronbach's alpha were greater than 0.7 the itemtotal correlations were more than 0.3 (Hair, Anderson, Tatham, \& Black, 1998). Then, Exploratory Factor Analysis (EFA) was used to ensure validity of the scale and to explore factor structure. KMO must be larger than 0.5. If KMO is lower than 0.5 is not suitable, exploratory factor analysis should not be performed. Total variance explained must be greater than $50 \%$ and the factor loading must be greater than or equal to 0.5 within a factor (Gerbing \& Anderson, 1988). Ordinary Least Squares (OLS) method has then been performed. 
Table 1: The item measure

\begin{tabular}{|c|c|c|}
\hline No & Factor (code) & Source \\
\hline & Work characteristics (WC) & \multirow[t]{5}{*}{ (Barnabé \& Burns, 1994) } \\
\hline 1 & WI have formal rights within my work (WC1). & \\
\hline 2 & My work is interesting and creative (WC2). & \\
\hline 3 & My work is beneficial for the society (WC3). & \\
\hline \multirow[t]{2}{*}{4} & The work gives me opportunities to develop myself (WC4). & \\
\hline & Wage and welfare (WW) & \multirow[t]{5}{*}{ (Munyengabe et al., 2016) } \\
\hline 5 & My income is equal to the completed tasks (WW1). & \\
\hline 6 & I feel my income is fair (WW2). & \\
\hline 7 & My income reflects what I have contributed to the university (WW3). & \\
\hline \multirow[t]{2}{*}{8} & Wage and welfare are at the same level of other occupations (WW4). & \\
\hline & Social recognition (SR) & \multirow[t]{4}{*}{ (Munyengabe et al., 2017) } \\
\hline 9 & Our contributions are recognized (SR1). & \\
\hline 10 & Our achievements are recognized and rewarded (SR2). & \\
\hline \multirow[t]{2}{*}{11} & There is accurate and fair performance appraisal at work (SR3). & \\
\hline & Peer relationships (PR) & \multirow{5}{*}{$\begin{array}{l}\text { (Munyengabe et al., 2017; } \\
\text { Skaalvik \& Skaalvik, 2018) }\end{array}$} \\
\hline 12 & I receive respect from colleagues (PR1). & \\
\hline 13 & I can often receive support from colleagues at work (PR2). & \\
\hline 14 & I get sincere suggestions and comments from colleagues (PR3). & \\
\hline \multirow[t]{2}{*}{15} & I am recognised by the colleagues (PR4). & \\
\hline & Training and promotion opportunities (PO) & \multirow[t]{4}{*}{ (Frenkel \& Bednall, 2016) } \\
\hline 16 & There are many opportunities for studying abroad (PO1). & \\
\hline 17 & The school has fair promotion policy (PO2). & \\
\hline \multirow[t]{2}{*}{18} & There are many opportunities for personal growth and development (PO3). & \\
\hline & Leader caring (LC) & \multirow[t]{5}{*}{ (Rahbi et al., 2017) } \\
\hline 19 & Leaders always consult the subordinates before giving decision (LC1). & \\
\hline 20 & Leaders are friendly and approachable (LC2). & \\
\hline 21 & Leaders always support lecturers at work (LC3). & \\
\hline \multirow[t]{2}{*}{22} & Leaders give fair and impartial evaluation (LC4) & \\
\hline & Teacher-student interaction and student's attitude (IA) & \multirow[t]{6}{*}{ (Munyengabe et al., 2017) } \\
\hline 23 & There is student-to-lecture interaction (IA1) & \\
\hline 24 & Students are interested in the lecture (IA2) & \\
\hline 25 & I earn the student's respect (IA3). & \\
\hline 26 & I receive objective assessment from students (IA4) & \\
\hline \multirow[t]{2}{*}{27} & I and my students are closed to each other (IA5) & \\
\hline & Work motivation (WM) & \multirow[t]{7}{*}{ (GebrekirosHagos, 2015) } \\
\hline 28 & I receive the respect from the society (WM1). & \\
\hline 29 & State policies show appreciation to teachers (WM2). & \\
\hline 30 & I am supported at work (WM3). & \\
\hline 31 & I expect to continue teaching until retirement (WM4). & \\
\hline 32 & I will conscientiously impart to the student the knowledge and skills (WM5). & \\
\hline 33 & I made the right choice with my career (WM6) & \\
\hline
\end{tabular}




\section{Results and Discussion}

\subsection{Descriptive Statistics}

The demographic information is shown as in Table 2. Descriptive statistics show that the responses are diversified when the values are in the range from 3.286 to 4.144 . The most appreciated factor is Work characteristics (WC) with the value of 4.144. The least appreciated factor is Wage and welfare (WW) with the value of 3.286. This confirms that Wage and welfare has still many limitations, meanwhile lecturers are more interested in Work characteristics.

\subsection{Exploratory Factor Analysis}

Before conducting regression analysis, scale reliability and validity is examined. Cronbach's alpha coefficient of 0.6-0.7 indicates an acceptable level of reliability, and 0.8 or greater a very good (Peterson, 1994). Table 3 shows that nearly all of the Cronbach's Alpha values are greater than 0.8. Only PO factor is with the Cronbach's alpha value of 0.795 . It can be concluded that all the scales measured are reliable.

After assessing the reliability of scales by Cronbach's alpha, a total of 27 items are used in the exploratory factor

Table 2: Demographic information

\begin{tabular}{|c|c|c|c|}
\hline \multicolumn{2}{|c|}{ Demographic variable } & \multirow{2}{*}{$\frac{\text { Number }}{104}$} & \multirow{2}{*}{$\begin{array}{c}\text { Percentage } \\
55.0 \%\end{array}$} \\
\hline Gender & Male & & \\
\hline & Female & 85 & $45.0 \%$ \\
\hline \multirow[t]{2}{*}{ Marital status } & Married & 160 & $84.7 \%$ \\
\hline & Single & 29 & $15.3 \%$ \\
\hline \multirow[t]{4}{*}{ Age group } & 30 or below & 15 & $7.9 \%$ \\
\hline & $31-41$ & 133 & $70.4 \%$ \\
\hline & $41-50$ & 30 & $15.9 \%$ \\
\hline & 51 or above & 11 & $5.8 \%$ \\
\hline \multirow{4}{*}{$\begin{array}{l}\text { Tenure } \\
\text { (years) }\end{array}$} & 3 or below & 22 & $11.6 \%$ \\
\hline & $3-5$ & 14 & $7.4 \%$ \\
\hline & 5 or above & 151 & $79.9 \%$ \\
\hline & Retirement & 2 & $1.1 \%$ \\
\hline \multirow{4}{*}{$\begin{array}{l}\text { Teaching } \\
\text { position }\end{array}$} & Full professor & 2 & $1.1 \%$ \\
\hline & $\begin{array}{l}\text { Associate } \\
\text { professor }\end{array}$ & 7 & $3.7 \%$ \\
\hline & Doctor & 68 & $36.0 \%$ \\
\hline & Master & 112 & $59.3 \%$ \\
\hline
\end{tabular}

analysis (EFA). The first results of testing the validity of scales by the exploratory factor analysis shows that $\mathrm{KMO}=0.727$, Sig. (Bartlett's Test) $=0.000<0.005$. As shown in Table 4, the EFA results showed that the scale has adequate internal consistency (Hair et al., 1998). The KMO value and the result of Bartlett's Test confirm that a satisfactory factor analysis to proceed.

Seven factors are with Eigenvalues (the total amount of variance that can be explained by a given principal component) greater than 1 . These components are retained the (accumulated) percentage of explained variance (73.412\%) (Gerbing \& Anderson, 1988). Thus, based on rotated component matrix from EFA analysis, there are 7 factors that are created from 27 items: Factor 1 includes 4 items, named as Work characteristics (WC); factor 2 includes 4 items, named as Wage and welfare (WW); Factor 3 includes 3 items, named as Wage and welfare (WW); factor 4 includes 4 items, named as Peer relationships (PR); factor 5 includes 3 items, named as Training and promotion opportunities (PO); factors 6 includes 4 items, named as leader caring (LC); factor 7 includes 5 items, named as Teacher-student interaction and student's attitude (IA).

Table 3: Test of reliability and quality of scale

\begin{tabular}{|l|l|c|}
\hline Factor & \multicolumn{1}{|c|}{ Item } & $\begin{array}{c}\text { Cronbach's } \\
\text { Alpha }\end{array}$ \\
\hline $\begin{array}{l}\text { Work } \\
\text { characteristics } \\
\text { (WC) }\end{array}$ & $\begin{array}{l}\text { WC1, WC2, WC3, } \\
\text { WC4 }\end{array}$ & 0.804 \\
\hline $\begin{array}{l}\text { Wage and welfare } \\
\text { (WW) }\end{array}$ & $\begin{array}{l}\text { WW1, WW2, WW3, } \\
\text { WW4 }\end{array}$ & 0.875 \\
\hline $\begin{array}{l}\text { Social recognition } \\
\text { (SR) }\end{array}$ & SR1, SR2, SR3 & 0.806 \\
\hline $\begin{array}{l}\text { Peer relationships } \\
\text { (PR): }\end{array}$ & PR1, PR2, PR3, PR4 & 0.817 \\
\hline $\begin{array}{l}\text { Training and } \\
\text { promotion } \\
\text { opportunities (PO) }\end{array}$ & PO1, PO2, PO3 & 0.795 \\
\hline \begin{tabular}{l} 
Leader caring (LC) \\
\hline $\begin{array}{l}\text { Teacher-student } \\
\text { interaction and } \\
\text { student's attitude } \\
\text { (IA) }\end{array}$
\end{tabular} & IA1, IA2, IA3, IA4, IA5 & 0.951 \\
\hline $\begin{array}{l}\text { Work motivation } \\
\text { (WM). }\end{array}$ & $\begin{array}{l}\text { WM1, WM2, WM3, } \\
\text { WM4, WM5, WM6 }\end{array}$ & 0.894 \\
\hline
\end{tabular}


Table 4: Results of exploratory factor analysis for independent variables

\begin{tabular}{|c|c|c|c|c|c|c|c|}
\hline \multirow{2}{*}{ Item } & \multicolumn{7}{|c|}{ Component } \\
\hline & 1 & 2 & 3 & 4 & 5 & 6 & 7 \\
\hline IA5 & .945 & & & & & & \\
\hline IA3 & .914 & & & & & & \\
\hline IA4 & .908 & & & & & & \\
\hline $\mathrm{IA} 2$ & .907 & & & & & & \\
\hline IA1 & .874 & & & & & & \\
\hline WW4 & & .878 & & & & & \\
\hline WW3 & & .872 & & & & & \\
\hline WW1 & & .833 & & & & & \\
\hline WW2 & & .814 & & & & & \\
\hline LC3 & & & .886 & & & & \\
\hline LC2 & & & .873 & & & & \\
\hline LC4 & & & .845 & & & & \\
\hline LC1 & & & .654 & & & & \\
\hline PR2 & & & & 927 & & & \\
\hline PR4 & & & & .808 & & & \\
\hline PR3 & & & & .738 & & & \\
\hline PR1 & & & & .736 & & & \\
\hline WC1 & & & & & .826 & & \\
\hline WC3 & & & & & .793 & & \\
\hline WC4 & & & & & .775 & & \\
\hline WC2 & & & & & .756 & & \\
\hline $\mathrm{PO} 2$ & & & & & & .873 & \\
\hline $\mathrm{PO} 3$ & & & & & & .842 & \\
\hline P01 & & & & & & .765 & \\
\hline SR1 & & & & & & & .889 \\
\hline SR3 & & & & & & & .830 \\
\hline SR2 & & & & & & & .794 \\
\hline Eigenvalues & 4.219 & 2.991 & 2.865 & 2.675 & 2.584 & 2.290 & 2.198 \\
\hline Cumulative (\%) & 15.624 & 26.702 & 37.314 & 47.223 & 56.791 & 65.271 & 73.412 \\
\hline \multicolumn{6}{|c|}{ Kaiser-Meyer-Olkin Measure of Sampling Adequacy. } & \multicolumn{2}{|c|}{0.727} \\
\hline \multirow{3}{*}{$\begin{array}{l}\text { Bartlett's Test of } \\
\text { Sphericity }\end{array}$} & \multicolumn{5}{|c|}{ Approx. Chi-Square } & \multicolumn{2}{|c|}{3108.583} \\
\hline & \multicolumn{5}{|c|}{ Df } & \multicolumn{2}{|c|}{351} \\
\hline & \multicolumn{5}{|c|}{ Sig. } & \multicolumn{2}{|c|}{0.000} \\
\hline
\end{tabular}

According to the results in Table 5, KMO $=0.901$ so factor analysis is appropriate. Accordingly, sig. of Bartlett's test is 0.000 , so the variables are correlated in the overall (Joseph F Hair, Black, Babin, Anderson, \& Tatham, 2006). With the results of KMO coefficient and Bartlett testing in the above table, it indicates that there are enough conditions to conduct factors analysis. The extraction method is principal component analysis. A factor with eigenvalues (variable amount explained by factor) which is greater than 1 is extracted from 6 original items; and cumulative with a value of $67.939 \%$ indicates that one factor explains $67.939 \%$ of the variability of data. Thus, based on component matrix from EFA analysis, there is a factor created from 6 items, named work motivation (WM). 
Table 5: Results of exploratory factor analysis for dependent variable

\begin{tabular}{|c|c|c|}
\hline Item & \multicolumn{2}{|c|}{ Component } \\
\hline WM3 & \multicolumn{2}{|c|}{.920} \\
\hline WM1 & \multicolumn{2}{|c|}{.866} \\
\hline WM2 & \multicolumn{2}{|c|}{.803} \\
\hline WM4 & \multicolumn{2}{|c|}{.799} \\
\hline WM6 & \multicolumn{2}{|c|}{.782} \\
\hline WM5 & \multicolumn{2}{|c|}{.766} \\
\hline Eigenvalues & \multicolumn{2}{|c|}{4.076} \\
\hline Cumulative (\%) & \multicolumn{2}{|c|}{67.939} \\
\hline \multicolumn{2}{|c|}{ Kaiser-Meyer-Olkin Measure of Sampling Adequacy. } & .901 \\
\hline \multirow[t]{3}{*}{ Bartlett's Test of Sphericity } & Approx. Chi-Square & 868.690 \\
\hline & Df & 15 \\
\hline & Sig. & .000 \\
\hline
\end{tabular}

Table 6: The models' regression results

\begin{tabular}{|c|c|c|c|c|c|c|c|c|}
\hline \multirow{2}{*}{\multicolumn{2}{|c|}{ Model }} & \multicolumn{2}{|c|}{$\begin{array}{l}\text { Unstandardized } \\
\text { Coefficients }\end{array}$} & \multirow{2}{*}{$\begin{array}{c}\begin{array}{c}\text { Standardized } \\
\text { Coefficients }\end{array} \\
\text { Beta } \\
\end{array}$} & \multirow[t]{2}{*}{$\mathbf{T}$} & \multirow{2}{*}{ Sig. } & \multicolumn{2}{|c|}{ Collinearity Statistics } \\
\hline & & B & Std. Error & & & & Tolerance & VIF \\
\hline \multirow[t]{8}{*}{1} & (Constant) & -2.430 & .404 & & -6.019 & .000 & & \\
\hline & WC & .228 & .048 & .187 & 4.698 & .000 & .942 & 1.061 \\
\hline & LT & 155 & .039 & .161 & 4.002 & .000 & 921 & 1.086 \\
\hline & SR & .355 & .035 & .401 & 10.034 & .000 & .935 & 1.070 \\
\hline & $\mathrm{PR}$ & .029 & .058 & .020 & .492 & .623 & .937 & 1.067 \\
\hline & $\mathrm{CH}$ & .139 & .037 & .148 & 3.703 & .000 & .935 & 1.070 \\
\hline & QT & .142 & .035 & .168 & 4.060 & .000 & .866 & 1.154 \\
\hline & IA & .597 & .038 & .631 & 15.790 & .000 & .934 & 1.071 \\
\hline \multicolumn{9}{|c|}{ a. Dependent Variable: WM } \\
\hline \multicolumn{4}{|c|}{ Adjusted R Square $=.720$} & \multicolumn{3}{|c|}{$F($ ANOVA $)=69.985$} & \multicolumn{2}{|c|}{ Sig. $=.000$} \\
\hline
\end{tabular}

\subsection{The Impact of Factors on Work Motivation of Lecturers}

As shown in Table 6, the adjusted $\mathrm{R}$ Square is 0.720 . This means $72 \%$ of change in work motivation is explained by independent variables. Verification tests of ANOVA result Sig. $=0.000<0.01$. Thus, the $99 \%$ significance level can conclude regression model was fit. Based on regression analysis, all seven factors positively affect the work motivation of lecturers. In which Teacher-student interaction and student's attitude (IA) is most strongly affected with the standardized coefficient of 0.631 , followed by the Social recognition (SR) with standardized coefficients of 0.401 . The last is Peer relationships (PR) with the standardized coefficient of 0.020 .

\section{Conclusions}

Working motivation is the desire and willingness of lecturers to strengthen their efforts towards the achievement of university goals. The research is based on an initial research model that consists of seven groups of factors affecting the work motivation of the lecturers including Work characteristics (WC), Wage and welfare (WW), Social recognition (SR), Peer relationships (PR), Training and promotion opportunities (PO), Leader caring (LC) and Teacher-student interaction and student's attitude (IA). These findings are aligned with previous studies that have all seven variables have a positive effect on work motivation of lecturers. Thus, in order to enhance work motivation of the 
lecturers, it is needed to improve student attitudes toward lecturer. The study finding amounts to valuable policy recommendations, and the relevant authorities could use social recognition as an important factor and should take steps to enhance the deeply held values and norms such as respect to lecturers, obedience, recognition and respect of the teaching profession, etc. within the society to increase job satisfaction of academic staff members.

Our study is without limitations. Firstly, the study was conducted only in universities in Hanoi, Vietnam; and therefore the findings and related conclusions may not be able to generalized and compared with rest of the nation. As future research directions, it is suggested to consider more affecting factors on job motivation among university academic faculty members.

\section{References}

Aaronson, D., Barrow, L., \& Sander, W. (2007). Teachers and student achievement in the Chicago public high schools. Journal of Labor Economics, 25(1), 95-135.

Ai, T. H., My, T. P. T., \& Chieu, M. P. T. (2019). Work motivation of lecturers in non-public universities: the case of Ho Chi Minh City, Vietnam. The EUrASEANs: Journal on Global SocioEconomic Dynamics, 4(17), 46-58.

Amarasena, T. S. M., Ajward, A. R., \& Ahasanul Haque, A. K. M. (2015). Does social recognition impact job satisfaction of academic faculty members of state universities in Sri Lanka. International Journal of Recent Advances in Organizational Behaviour and Decision Sciences: An Online International Research Journal, 1(4), 540-553.

Barnabé, C., \& Burns, M. (1994). Teachers' job characteristics and motivation. Educational Research, 36(2), 171-185.

Baron, R. A. (1991). Motivation in work settings: Reflections on the core of organizational research. Motivation and Emotion, 15(1), 1-8.

Bos, J. T., Donders, N. C. G. M., Bouwman-Brouwer, K. M., \& Van der Gulden, J. W. J. (2009). Work characteristics and determinants of job satisfaction in four age groups: university employees' point of view. International Archives of Occupational and Environmental Health, 82(10), 1249-1259.

Frenkel, S. J., \& Bednall, T. (2016). How training and promotion opportunities, career expectations, and two dimensions of organizational justice explain discretionary work effort. Human Performance, 29(1), 16-32.

GebrekirosHagos, K. A. (2015). Study on factors affecting Job Satisfaction in Mekele University Academic staff at Adi-Haqi campus. International Journal of Scientific and Research Publications, 5(1),1-6.

Gerbing, D. W., \& Anderson, J. C. (1988). An updated paradigm for scale development incorporating unidimensionality and its assessment. Journal of Marketing Research, 25(2), 186-192.
Green, S. B. (1991). How many subjects does it take to do a regression analysis. Multivariate Behavioral Research, 26(3), 499-510.

Hair, J. F., Black, W. C., Babin, B. J., Anderson, R. E., \& Tatham, R. L. (2006). Multivariate data analysis (Vol. 6). Upper Saddle River, NJ: Pearson Prentice Hall.

Jusmin, A., Said, S., Bima, M. J., \& Alam, R. (2016). Specific determinants of work motivation, competence, organizational climate, job satisfaction and individual performance: A study among lecturers. Journal of Business and Management Sciences, 4(3), 53-59.

Lee, J. Y. (2018). The Effects of Job Characteristics on the Team Creativity of Distribution Companies: Moderating Effects of Transformational Leadership. Journal of Asian Finance, Economics and Business, 5(4), 161-172. http://doi. org/10.13106/jafeb.2018.vol5.no4.161

Mertler, C. A. (1992). Teacher motivation and job satisfaction of public school teachers. Columbus, $\mathrm{OH}$ : The Ohio State University.

Morrison, R. L., \& Nolan, T. (2009). I get by with a little help from my friends... at work. Kōtuitui: New Zealand Journal of Social Sciences Online, 4(1), 41-54.

Munyengabe, S., Haiyan, H., Yiyi, Z., \& Jiefei, S. (2017). Factors and levels associated with lecturers' motivation and job satisfaction in a Chinese university. Eurasia Journal of Mathematics, Science and Technology Education, 13(10), 6415-6430.

Munyengabe, S., He, H., \& Yiyi, Z. (2016). The Analysis of Factors and Levels Associated with Lecturers' Motivation and Job Satisfaction in University of Rwanda. Journal of Education and Practice, 7(30), 188-200.

Nguyen, H. M., Mai, L. T., \& Huynh, T. L. (2019). The Role of Transformational Leadership toward Work Performance through Intrinsic Motivation: A Study in the Pharmaceutical Field in Vietnam. Journal of Asian Finance, Economics and Business, 6(4), 201-212. https://doi.org/10.13106/jafeb.2019. vol6.no4.201

Pancasila, I., Haryono, S., \& Sulistyo, B. A. (2020). Effects of Work Motivation and Leadership toward Work Satisfaction and Employee Performance: Evidence from Indonesia. Journal of Asian Finance, Economics and Business, 7(6), 387-397. https://doi.org/10.13106/jafeb.2020.vol7.no6.387

Peterson, R. A. (1994). A meta-analysis of Cronbach's coefficient alpha. Journal of Consumer Research, 21(2), 381-391.

Phuong, N. N. D., Khuong, M. N., Phuc, L. H., \& Dong, L. N. T. (2018). The Effect of Two-Dimensional Factor on Municipal Civil Servants' Job Satisfaction and Public Policy Implications. Journal of Asian Finance, Economics and Business, 5(3), 133-142. http://doi.org/10.13106/jafeb.2018.vol5.no3.133

Rahbi, D. A., Khalid, K., \& Khan, M. (2017). The effects of leadership styles on team motivation. Academy of Strategic Management Journal, 16(3). Retrieved April 10, 2020 
from: https://www.abacademies.org/articles/the-effects-ofleadership-styles-on-team-motivation-6793.html

Skaalvik, E. M., \& Skaalvik, S. (2018). Job demands and job resources as predictors of teacher motivation and well-being. Social Psychology of Education, 21(5), 1251-1275.
Victor, A. A., \& Babatunde, E. G. (2014). Motivation and Effective Performance of Academic Staff in Higher Education (Case Study of Adekunle Ajasin University, Ondo State, Nigeria). Online Submission, 1(2), 157-163. 